\title{
Elavult a beszélgetés?
}

\author{
KOLOZSVÁRI ORSOLYA ${ }^{1}$ \\ Sherry Turkle (2015): Reclaiming Conversation: \\ The Power of Talk in a Digital Age. Penguin Books, New York, 436 p.
}

\section{Reclaiming: Conversation \\ The Power of Talk in a Digital Age

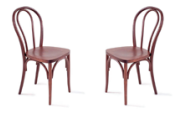 \\ Sherry Turkle}

Mit csinál éppen, miközben ezt a recenziót olvassa? Most őszintén, vajon hány ablak van egyszerre nyitva a számítógépén? Hány dologgal foglalatoskodik ebben a pillanatban? Lehet, hogy pont most kapott egy SMS-t, amire úgy érezte, rögtön válaszolnia kell? Vajon hányszor terelődik el a figyelme és szakítják félbe akár már csak jelen recenzió olvasása közben is? Frusztrálja, hogy ennyien tartanak igényt az idejére, és szívből vágyik rá, hogy igazi, mély kapcsolatot létesítsen a gyermekeivel, partnerével, barátaival, munkatársaival, de annak ellenére, hogy mennyi e-mailt vagy SMS-t küld és kommentárt posztol a közösségi médián, az áhított tartalmas együttlét valahogy nem jön össze? Hiányzik, hogy időnként egyedül is legyen és valóban meghallja a saját gondolatait? Sherry Turkle Reclaiming Conversation című könyve mindezekre a nagyon is aktuális kérdésekre keresi a választ, feltérképezve az élő párbeszéd hanyatlását a digitális korban és kiemelve annak fontosságát, hogy minél inkább visszacsempésszük az élet különböző területeire.

Turkle világszerte ismert szakértője a digitális korszaknak, a modern kommunikációs eszközöknek, a robotoknak és az emberek velük való viszonyának, valamint annak, hogy mindezek a változások miként formálták újra az életünket. Turkle nemcsak több évtizedes kutatási múltra tekint vissza ezekben a kérdésekben, hanem szociológiai és pszichológiai háttérrel is rendelkezik, ami még sajátosabbá teszi a szemszögét. Így keresve sem találhatnánk alkalmasabb szerzőt, aki az élőbeszéd hatalmát firtatja a digitális korszakban.

Mivel Turkle más munkáit is olvastam már, volt módom megfigyelni, hogy a kutatásmódszertana mindig nagyon alapos, gyakorlatilag kifogástalan. Jelen könyv esetében longitudinális kutatást folytatott és tiszteletreméltóan sok alannyal készített interjút, akik az élet számos különböző területén tevékenykednek, és a minta kor alapján is heterogén. Turkle alkalmaz tartalomelemzést, megfigyeléseket és kísérleteket is. A kutatása igen széles fókuszú, a módszertana pedig szintén több lábon áll, ezáltal az eredményei és végkövetkeztetései is meggyőzőek.

\footnotetext{
${ }^{1}$ College of Coastal Georgia, USA; kolozsvariors@gmail.com
} 


\section{RECENZIÓ}

Érdekes és a könyvet gazdagabbá varázsoló tényező, hogy a szociológiai és a pszichológiai szemszög mellett Turkle egy irodalmi-filozófiai klasszikushoz is visszanyúl, miközben a szemtől szembeni beszélgetéshez visszatérés fontosságát taglalja. A mű, amire utal, a Walden, Henry David Thoreau 19. századi amerikai író, filozófus klasszikusa. Amikor Thoreau egy kis erdei kunyhóba költözött, sokan remetének vélték, de Turkle hangsúlyozza, hogy ez messze nem így volt. Thoreau kereste a magányt, de azért, mert rádöbbent, hogy egyedüllétre van ahhoz szükség, hogy az ember megismerhesse önmagát és meghallja a saját gondolatait, de ezt a tudást leginkább úgy lehet kamatoztatni, hogy az ember értelmes, tartalmas párbeszédbe kezd embertársaival és részt vesz társadalmi párbeszédekben is. Thoreau filozófiája három lábon állt, és ennek szimbolizálására a kunyhójában három széket helyezett el. Egyet az egyedüllét számára, egy másikat a barátságnak, a harmadikat pedig a társadalomnak, úgy vélekedve, hogy mindegyikre szükség van egy kiegyensúlyozott ember életében. Turkle Reclaiming Conversation múve rávilágít, hogy olyan, mintha a technológia kihúzta volna alólunk ezeket a székeket, vagy legalábbis újrarendezte volna őket. Ennek az az eredménye, hogy a legtöbb ember állandó kapcsolatfelvételre törekszik, de közben visszariad az igazán mély beszélgetésektől.

Mivel az egyedüllét a párbeszéd szükséges előszobája, Turkle két fejezetet is szentel ennek a témának, és a későbbiekben is vissza-visszatér rá. Rávilágít, hogy az emberek, különösen a fiatalabb generáció tagjai gyakran képtelenek egyedül lenni. Ők (vagy talán mi magunk) kényelmetlennek találják (illetve találjuk) az egyedüllétet és állandóan a telefonjuk után nyúlnak, hogy mindig bekapcsolódjanak az élet körforgásába, és folyamatosan kapcsolatban legyenek (az, hogy kivel, kevésbé számít, mint a kapcsolatfelvétel maga). Így az embernek nincs módja megfelelö önreflexióra, hogy megismerje önmagát, ami akár az egyéniség torzulásához is vezethet. A „gondolkozom, tehát vagyok” elvét helyettesíti a „megosztok, tehát vagyok” (Turkle 2015: 47). Ha az emberek nem posztolnak, SMS-eznek, üzengetnek, sokan úgy érzik, hogy amit gondolnak és éreznek, az nem is létezik, illetve akár ők maguk sem léteznek. Így felépül egy „hamis én, ami másoknak megfelelni akaró előadásokból tevődik össze” (Turkle 2015: 62). Az előadások említése Erving Goffman szimbolikus-interakcionalista szociológus dramaturgiai elméletét idézi számomra, aki kifejtette, hogy a társadalmi szerepeinknek és a különböző társas szituációknak megfelelően mindnyájan szerepeket játszunk másoknak. Ezek az előadások az úgynevezett előszínpadon történnek, és a háttérszínpadon készülünk rájuk. Felvetődik bennem, hogy az állandó megosztást, posztolást, kapcsolatfelvételt igénylő személy háttérszínpada eltűnik. Mindig az előszínpadon van, folyamatosan szerepet játszik, ráadásul egyszerre több célközönségnek, hiszen a virtuális világban, amikor az sem biztos, hogy végül ki látja a posztokat, nem lehetséges olyan adott célközönségre szabott előadást nyújtani, mint szemtől szemben.

Szintén elgondolkodtató az algoritmusos én megjelenése, amiről Turkle a 81. oldalon ír. Ez az én az internetes kereséseinknek, a telefonunk és számítógépünk 


\section{RECENZIÓ}

által kidobott adathalmaznak az összesített masszája. Ezek az algoritmusok sokszor szinte jobban ismerik az érdeklődésünket, vágyainkat, mint mi magunk. Ez a leírás Charles Horton Cooley tükör-én fogalmára emlékeztet. Eszerint a társadalom tükröt tart elénk, és mások reakciói, visszajelzései alapján ismerjük meg magunkat. Vajon ezt a jelenséget fokozza a digitális, közösségi médiás, algoritmusos én formálódása? A telefonunk és számítógépünk veszi át a tükör szerepét, főleg ahogy egyre ritkulnak a szemtôl szemben történő interakciók?

A Thoreau-féle második pillér, a barátság széke a családokat, párkapcsolatokat, ismerősöket jelképezi Turkle könyvében. Számtalan témát felölel ez a rész, amelyekből jó néhányat valószínűleg mi magunk is tapasztaltunk. Szóba kerülnek a szórakozott szülők, akik telefont nyomogatva tolják a babakocsit vagy úgy ülnek a vacsoraasztalhoz. Turkle feltérképezi az SMS-ben veszekedő családokat, a párbeszéd helyett üzeneteket küldözgető barátokat, aki még ha együtt vannak, gyakran akkor is arról beszélnek, ami épp a telefonjukon történik. Lefedi ez a szekció a sürgető szükséget, hogy valaki rögtön válaszoljon egy SMS-re, az interneten és üzenetekben kibontakozó románcokat, illetve a szöveges üzenetben véget érő kapcsolatokat (vagy azt, hogy egyre inkább az SMS is hiányzik egy szakítás kommunikálásánál, marad helyette a nyomasztó csend). Számomra a legsokatmondóbb esetleírás a könyvben egy végzős egyetemista lány történetét boncolgatja, aki közvetlen az első intim együttléte után egy iskolatársával, amíg a fiú elmegy a mosdóba, előkapja a telefonját és gyorsan rápillant a letöltött randi applikációjára, hogy vajon vannak-e újonnan feliratkozott férfiak az applikáción. Mindezt annak ellenére teszi, hogy tetszik neki a fiú, akivel az imént együtt volt és máskor is szívesen randizna vele. Turkle hozzáteszi a történethez, hogy a harminc alattiak csak vállat vonnak a hasonló történetekre, így lehetséges, hogy nálam is csak a koromnak köszönhető, hogy egyáltalán említésre méltónak találtam ezt az esettanulmányt, mint a mai technológia és romantikus kapcsolati normák illusztrációját.

A társadalmat szimbolizáló székek, Thoreau analógiáját követve, Turkle munkájában az oktatáson, munkán és közszférán keresztül kerülnek bemutatásra. Ezeken a területeken szintén jellemző az igazi, mély beszélgetések kerülése, az egyszerre több tevékenységben elmerülés és a technikára hagyatkozás. A Reclaiming Conversation 2015-ben íródott, de a témái ma is aktuálisak, sőt napjainkban ez talán még inkább igaz. Ezt a recenziót 2020 júniusában írom, amikor az ezt megelőző hónapokban a COVID-19 világjárvány korábban példátlan intézkedéseket tett szükségessé. A munkánk, életünk, kapcsolattartásunk az elmúlt időszakban az eddiginél még fokozottabban az online térbe tolódott. Az elszigeteltség nőtt, a szemtől szembeni beszélgetések nagymértékben redukálódtak. Bár egy ilyen kényszerhelyzet lassításra, több és bensőségesebb családi együttlétre inspirálhatja az embereket, és ez sok esetben meg is történt, más szempontból még nagyobb teret nyerhet az egymástól elfordulás, az élő párbeszédtől tartózkodás, a kapcsolatok kerülése, illetve teljesen telefonra és online térbe korlátozása. Bár itt egy átmeneti helyzetről van szó, elképzelhetően 


\section{RECENZIÓ}

akár hosszú távon fokozhatja a Turkle által leírt folyamatokat és nem kedvez azon módszerek alkalmazásának, amelyeket ő javasol az élő párbeszéd „feltámasztására” és a modern technika jótékony használatára. Ezek közé tartozik az elcsendesedés, az egyszerre egy dologra koncentrálás (a karantén alatt home office-ban dolgozó szülők valószínűleg egyetértenének, hogy egy világjárvány és a miatta szükségessé vált intézkedések nem sok lehetőséget hagynak az egyszerre egy dologra fókuszálásra), szent és sérthetetlen terek létrehozása a beszélgetésre, diskurzus olyanokkal, akikkel nem értünk egyet és a nem visszariadás a nehéz beszélgetésektől.

Az angolul jól beszélők bizonyára értékelik Turkle választékos, szórakoztató, lényeget megragadó stílusát is. Azonban amihez még az írásnál is jobb érzéke van, az az együttérzés. Ő valójában az emberségünket és empátiára való készségünket félti az elmúlt években bekövetkezett folyamatoktól, hiszen meglátása szerint csakis szemtől szembeni interakcióban tudjuk az empatikus képességünket kifejleszteni. Számtalan példát sorol, amelyek a csökkenő empátiánkat jelzik, például ahogy az iskolában bánnak egymással a gyerekek, és főleg az éterben lezajló szóbeli bántalmazások nem adnak módot együttérezni a szenvedő alannyal, átérezni a helyzetét, hiszen a következményeknek nincs abban a pillanatban látható, érzékelhető nyoma. Az sms-ben vagy a kommunikáció hirtelen, váratlan beszüntetésével történő szakítások elterjedése is a zsugorodó empátiánkra utal.

Az utolsó fejezetek egyikében a gondoskodásra kifejlesztett robotokról gondolkodik el Turkle, amelyeket gyerekfelvigyázásra, idősgondozásra, vagy pszichoterápiára gyártanak. Elmagyarázza, hogy jó néhány interjúalanya esetleg szívesen szert tenne robot háziállatra, barátokra, vagy akár szeretőre, mert ezek a kockázat nélküli kapcsolat lehetőségét nyújtják. „Lassan úgy bánunk a gépekkel, mintha majdnem emberek volnának, miközben olyan szokásokat fejlesztünk ki magunkban, amelyek által úgy kezeljük az embereket, mintha majdnem gépek lennének." (Turkle 2015: 345). Ez a mondat rendkívül elgondolkodtató és számomra kifejezetten nyugtalanító. Turkle-höz hasonlóan én is remélem, hogy olyan messze nem kalandozunk a párbeszédtől és empátiától, hogy az emberségünk fontos része csorbát szenvedjen.

Számos erősségét felsoroltam már Turkle munkájának, mint például a kutatásmódszertana és stílusa, így nem is olyan könnyủ az esetleges hiányosságaira rámutatni. Azonban biztos vagyok benne, hogy a technika elkötelezett hívei nem értenének egyet Turkle következtetéseivel. Bár engem nagyrészt sikerült meggyőznie, annyit elismerek, hogy nagyobb mértékben bemutathatta volna azért a technika előnyeit is. Előző műveiben ezt fokozottabban megtette, és itt talán a cél, hogy felhívja a figyelmet a lehetséges veszélyekre. Kevés interjúalanya volt az idősebb generációkból, belőlük lehetett volna célzottan több is, illetve tágabb nemzetközi kitekintést is nyújthatott volna a vizsgált kérdésekben. Mint tudjuk, kor, társadalmi osztálybeli és globális egyenlőtlenségek léteznek a digitális eszközökhöz hozzáférésben és azok használatában, tehát érdekes lenne ugyanezeket a témákat generációkat, társadalmi osztályokat és globális egyenlőtlenségeket átívelően is kutatni. 


\section{RECENZIÓ}

Ez a könyv bárkinek szól, akinek volt valaha okostelefonja vagy számítógépe, randizott valaha online vagy telefonos applikáció segítségével, akinek gyermekei vannak, aki tanár vagy munkaadó, vagy egyszerűen érdekli, hogy szociológiai és pszichológiai szempontból milyen hatása van a technikának az egyénre és társadalomra. Bármilyen társadalomtudós haszonnal forgathatja ezt a munkát, illetve szociológia, pszichológia, kommunikáció és filozófia szakos diákok egyaránt profitálhatnak belőle. Szociológia kurzusok oktatása során bármelyik óra tanulságos olvasmánya lehet, amelynek témája a társadalmi problémák, a normák és deviancia, szociálpszichológia, vagy a családszociológia. Ahogy a felsorolásból kiderül, Turkle mondanivalója, legalábbis a fejlett, magasabb jövedelmű társadalmakban, szinte mindannyiunkat érint, ezért szívből ajánlom bárkinek, aki beszél angolul. Mivel elég termékeny szerzőről van szó, úgy sejtem előbb-utóbb a 2020-as világjárvány potenciális hatásairól is ír majd, időközben pedig mi magunk is megfigyelhetjük, mind egyéni, mind tudományos módon, hogy akár a pandémia, akár más társadalmi folyamatok következményeként hogyan használjuk majd a technikát, a modern kommunikációs eszközöket, és a párbeszéd és empátia hova alakul a jövőben. Én személy szerint remélem, hogy sosem „mennek ki a divatból”, és az eljövendő generációk életében is lesz helyük. 